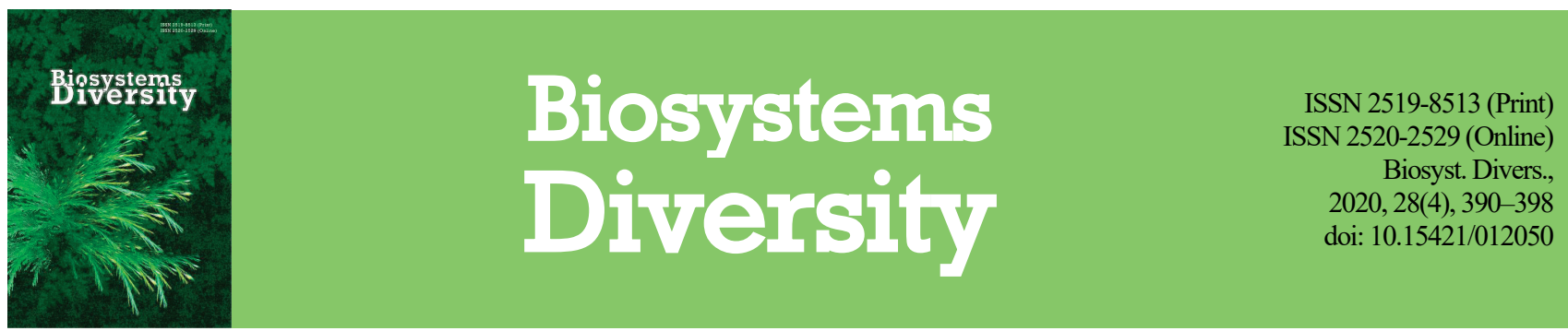

\title{
The small-scale variation of herb-layer community structure in a riparian mixed forest
}

\author{
Y. O. Zhukova*, N. V. Yorkina**, V. S. Budakova**, O. M. Kunakh* \\ *Oles Honchar Dnipro National University, Dnipro, Ukraine \\ **Bogdan Khmelnitsky Melitopol State Pedagogical University, Melitopol, Ukraine
}

Article info

Received 28.09.2020

Received in revised form 22.10.2020

Accepted 24.10.2020

Oles Gonchar Dnipro National University,

Gagarin av., 72,

Diipro, 49000, Ukraine

Tel.: +38-098-858-23-79.

E-mail:

kunah_olga@ukr.net

Bogdan Khmelnitsk

Melitopol State

Pedagogical University

Hetmanska st., 20,

Melitopol, 72318, Ukraine.

E-mail:

nadyayork777@gmail.com

\section{Zhukova, Y. O., Yorkina, N. V., Budakova, V. S., \& Kunakh, O. M. (2020). The small-scale variation of herb-layer community structure in a riparian mixed forest. Biosystems Diversity, 28(4), 390-398. doi:10.15421/012050}

The ground vegetation layer is the most diverse plant community in forest ecosystems. We have shown the role of spatial variables, soil properties and overstorey structure in spatial variation of the herb-layer community in a riparian mixed forest. The research was conducted in the "Dnipro-Orils'kiy" Nature Reserve (Ukraine). The research polygon was located in the forest in the floodplain of the River Protich, which is a left tributary of the River Dnipro. Plant abundance was quantified by measuring cover within an experimental polygon. The experimental polygon consisted of 7 transects, each comprising 15 test points. The distance between the rows in the site was $3 \mathrm{~m}$. At the site we established a plot of $45 \times 21 \mathrm{~m}$, with 105 subplots of $3 \times 3 \mathrm{~m}$ organized in a regular grid. A list of vascular plant species was composed for each $3 \times 3 \mathrm{~m}$ subplot along with visual estimates of species cover projection. The plant community was represented by 43 species, of which $18.6 \%$ were phanerophytes, $39.5 \%$ were hemicryptophytes, $9.3 \%$ were therophytes, $7.0 \%$ were geophytes. An overall test of random labelling revealed the total nonrandom distribution of the tree stems within the site. The species-specific test of random labelling showed the nonrandom segregated distribution of Acer tataricum, Pyrus communis, Quercus robur, and Ulmus laevis. Crataegus monogyna and Euonymus europaeus were distributed randomly. The nearest neighbour of Acer tataricum was less likely to be Ulmus laevis. There was no direct spatial connection between Acer tataricum and other trees. Crataegus monogyna, Pyrus communis, Quercus robur and Euonymus europaeus were not segregated from all other species. The nearest neighbour of Ulmus laevis was less likely to be Acer tataricum. Constrained correspondence analysis (CCA) was applied as ordination approach. The forward selection procedure allowed us to select 6 soil variables which explain $28.3 \%$ of the herb-layer community variability. The list of the important soil variables includes soil mechanical impedance (at the depth $0-5,30-35,75-80$, and $95-10 \mathrm{~cm}$ ), soil moisture, and soil bulk density. The variation explained by pure spatial variables accounted for $11.0 \%$. The majority of the tree-distance structured variation in plant community composition was broad-scaled. The spatial scalograms were left-skewed asymmetric. Significant relationship was found between the pure spatial component of the community variation and a number of phytoindicator estimations, most important of which were the variability of damping and humidity. Tree stand was obseerved to be a considerable factor structuring both the herb-layer community and spatial variation of the physical properties of soil.

Keywords: overstorey structure; soil properties; spatial pattern; phytoindication; scalogram; spatial eigenvector mapping.

\section{Introduction}

Floodplain forest ecosystems form centers of biological diversity (Schnitzler et al., 2005; Zhukov \& Gubanova, 2015b; Brygadyrenko, 2016; Schindler et al., 2016). These ecosystems occupy a small part of the territory of the steppe zone of Ukraine, but give refuge to a large variety of soils, vegetation and animal communities (Gritsan et al., 2019). The environmental processes occurring at landscape levels are directly reflected in the state of floodplain ecosystems (Ward et al., 2002; Zhukov \& Gubanova, 2015a; Talbot et al., 2018). The small-scale variation of herb-layer community structure is affected by the soil properties, overstorey structural features and factors of a neutral nature. It should be noted that the nature of the influence of trees on herbaceous plants is much more complicated and involves the impact of trees on the habitat by modulating the availability of resources to other species (Jones et al., 1994). The spatial component is presented in the variability of soil properties and the overstorey effects on the understorey plant community. The nearest distance to the tree species can be considered as a very apparent measure of influence on the herbaceous plants. The arrangement of different tree species can significantly complicate the structure of ecological space. The distance to the nearest tree is an easy and obvious measure of the impact of the overstorey both on the herbaceous layer and soil (Zhukov et al., 2019). The herb-layer of forest ecosystems is affected by a complex of factors, the source of which are soil conditions, the structure of a overstorey, interspecies interactions at the level of the herb-layer community and the factors of neutral nature. Neutral theory is based on the presumption that species of the community are 'neutral' in their ecological fitness (Burns et al., 2016). An important feature is that almost all of these factors are spatially structured. The neutral processes may be modeled by means of the spatial factors (Cottenie, 2005). The spatial structure has hierarchy of a certain scale. The environmental variables explain mostly broadscaled spatial patterns (Chudomelová et al., 2017). The factors of different nature are mainly manifested at different scale levels, which is especially important for assessing those factors that cannot be directly measured or are difficult to measure (Laliberté et al., 2009). This is especially true for the neutral nature factors, which in a time dimension occupy a considerably wider range than the duration of conventional environmental observations. The soil physical properties form fine-scale patterns of an endogenous nature. Also fine-scale morphological soil structure may occur due to influence of trees. Morphological structure of soil on the fine-scale level is interpreted in terms of soil ecomorphs. The fine-scale structured soil patterns demonstrate ability to affect the herb layer stratum (Zhukov \& Zadorozhnaya, 2016). Using soil variables, one may explain both broad-scale and fine-scale spatial patterns (Zhukov et al., 2019).

The estimation of the influence of the spatial organization of overstorey on the herb-layer is also a difficult task. Various components in the soil properties are highly correlated (Paluch \& Gruba, 2012). The impact of trees has a complex spatial organization, or is very changeable in time. Trees are capable of modifying properties of soil in neighbouring territories (Binkley \& Giardina, 1998). The latter circumstance is particularly 
related to the light regime. Sunlight penetration through the canopy directly determines the spatial pattern of the herb-layer community structure (Blank \& Carmel, 2012). The amount of light that passes through the tree crown depends on many factors that vary significantly during the day, the seasons and throughout the year. The light variability mediated by the stand density is the important environmental regime which determines the interactions between organisms and their physical environments (Stohlgren et al., 2000). In this regard, the integrated indicators of the plant community response to tree stand effect has a certain advantage, as they reflect a regular pattern of the impact of trees on the environment (Zhukov, 2015a).

The estimation of impact of different sources is complicated due to their mutual interrelation. Tree species have a significant impact on humus characteristics, which significantly explain the distribution of forest understorey species (Oijen et al., 2005). This relationship can be functional or indirect. Trees also affect variability of the soil conditions, and soil conditions affect the dynamics of growth and condition of trees. General regimes, caused by relief or parent materials, take effect both on trees and soils.

The objective of this study was evaluation of the role of spatial variables, soil properties and overstorey structure in spatial variation of the herb-layer community in riparian mixed forest.

\section{Materials and methods}

The studies were conducted in the "Dnipro-Orils'kiy" Nature Reserve (Ukraine) (Fig. 1).
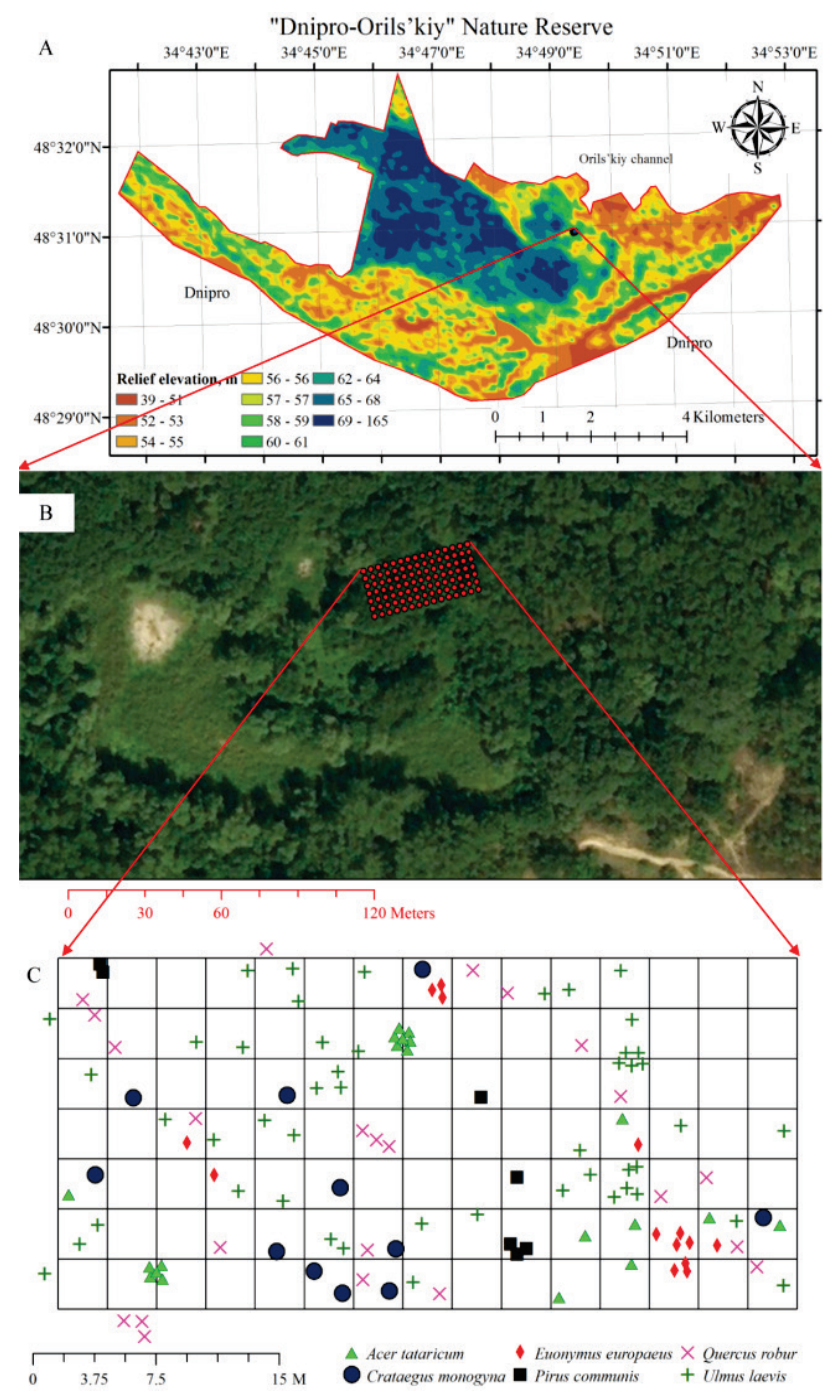

Fig. 1. Arrangement of experimental polygon and the sampling points: $a$ - map of the "Dnipro-Orils'kiy" Nature Reserve; $b$ - satellite image of the territory around the research polygon; $c$-scheme of the research polygon and tree species individual locations
The experimental polygon ( $\left.48^{\circ} 30^{\prime} 56^{\prime \prime} \mathrm{N}, 34^{\circ} 49^{\prime \prime} 21^{\prime \prime} \mathrm{E}\right)$ was located in a forest in the floodplain of the River Protich, left tributary of the River Dnipro. The territory has a temperate-continental climate with an annual mean maximum temperature for the decade 2008-2018 equaling $25.7^{\circ} \mathrm{C}$, and a minimum of $-10.0^{\circ} \mathrm{C}$, and with a mean annual precipitation of approximately $565 \mathrm{~mm}$ (20 year average according to data of the Dnipro meteorological station). The study site comprises 0.945 ha of deciduous woodland bordered by an arena terrace above the floodplain of the River Dnipro. Forests in the steppe zone of Ukraine have a very restricted distribution, usually appearing as "islands", which implies a considerable impact of the surrounding non-forest environment (Zhukov et al., 2019).

The abundance of plant species was quantified by measuring cover within each subplot of the experimental polygon. The experimental polygon consisted of 7 transects, each transect comprising 15 subplots with the size of $3 \times 3 \mathrm{~m}$ (Zhukov et al., 2019). The adjacent subplots were in close proximity.

The projective cover of plant species was recorded at ground level (hemicryptophytes, therophytes, and geophytes), understorey (up to $2 \mathrm{~m}$ height, nanophanerophytes) and canopy (above $2 \mathrm{~m}$ height, phanerophytes). We were able to make species level identification for all subplots. Seedlings and saplings of woody species were later excluded from the analyses. Within the plot, all tree stems $\geq 20 \mathrm{~cm}$ in diameter at breast height were measured and mapped. Dixon's segregation index was calculated for tree species to quantify their relative spatial mixing. The measure of segregation describes the tendency of one species to be associated with itself or with other species (Dixon, 2002).

The investigated biotope may be identified as G1.22 Mixed oak-elmash woodland of great rivers according to the EUNIS classification or 91F0 Riparian mixed forests of Quercus robur, Ulmus laevis and Ulmus minor, Fraxinus excelsior or $F$. angustifolia, along the great rivers of the Atlantic and Middle-European provinces (Ulmenion minoris) according to the Council Directive 92/43/EEC (Borsukevish \& Onishenko, 2018). In syntaxonomic aspect the vegetation can be identified as follows: Class Alno glutinosae-Populetea albae P. Fukarek et Fabijanić 1968 Ordo Alno-Fraxinetalia excelsioris Passarge et G. Hofmann 1968 Alliance Alnion incanae Pawłowski, Sokołowski et Wallisch 1928 Ass. Ficario-Ulmetum minoris Knapp 1942 em. J. Matuszkiewicz 1976

Subass. Ficario-Ulmetum minoris franguletosum alni Onyshchenko 2009

On the basis of geobotanical descriptions, we performed phytoindicative assessment of environmental factors according to Didukh (Didukh, 2011). Measurement of soil mechanical impedance was carried out in the field using a hand Eijkelkamp penetrometer, to a depth of $100 \mathrm{~cm}$ with interval of $5 \mathrm{~cm}$. The mean error of the measurement results obtained using the device is $\pm 8 \%$. The measurements were made by a cone with a cross-sectional dimension of $2 \mathrm{~cm}^{2}$. Within each measurement point, the mechanical impedance of the soil was determined in a single repeatability (Zhukov, 2015b). To measure the electrical conductivity of the soil in situ, a HI 76305 sensor was used (Hanna Instruments, Woonsocket, R. I.). The soil bulk density was determined using Kachinsky classification, and soil moisture was determined using weight method. The aggregate structure was evaluated by the dry sieving method according to Savinov (Zhukov et al., 2015). The percentage content of such fractions accounted for: $<0.25,0.25-0.5,0.5-1,1-2,2-3,3-5,5-7,7-10,>10 \mathrm{~mm}$. Thickness of litter layer was measured with a ruler at 5 sampling points per sample subplot. According to the WRB (IUSS Working Group WRB 2015), the soil was identified as Fluvic Calcic Gleysol (Loamic, Humic) (Yakovenko et al., 2019).

As plant cover data tended to be left-skewed (J-shaped), right skewed (L-shaped) or U-shaped, the statistical presumptions of the plant cover data normality were rejected. Plant cover was assumed as being betadistributed (Damgaard \& Irvine, 2019). The shape parameters of beta distribution were found on the basis of the experimental data by means of the betaCvMfit function of the R (R Core Team, 2020) package RobPer (Thieler et al., 2016). The nonparametric bootstrap confidence interval of the plant cover projection was estimated by means of the boot.ci function of the R package boot (Canty \& Ripley, 2016).

Constrained correspondence analysis (CCA) was applied to model of the variance in herb layer species composition (Ter Braak, 1986). Before the analyses, percentage cover of species was arcsine-transformed. Soil 
mechanical impedance, soil electrical conductivity, thickness of litter layer, moisture and soil bulk density were log-transformed. First the significance of CCA global model including all soil variables was tested. A soil model based on the forward selection of soil variables was developed with double stopping rule (alpha significance level and the R2adj were calculated using all explanatory variables) (Blanchet et al., 2008). Variables were retained only with a significant relationship to community composition ( $\mathrm{P}<0.05,9999$ permutations). The models' marginal effect was computed, in which each selected soil variable was used separately as a predictor of community composition. The significances of all the models were tested, and R2adj was extracted.

The geographic coordinates of sampling locations were used to generate a set of orthogonal eigenvector-based spatial variables (dbMEMs), each of them representing a pattern of particular scale within the extent of the sampling area (Borcard \& Legendre, 2002). The forward-selection procedure on partial RDAs with previously selected soil factors as covariables was applied to the subset of spatial variables. The significance of soil models with selected spatial variables as covariables was tested using the Monte Carlo permutation test (9999 permutations) (Zhukov et al., 2019).

The distance matrix from each species to the nearest tree was applied as a measure of spatial structure of overstorey The distance matrix of sampling locations provided the opportunity to generate eigenvectorbased spatial variables (dbMEMs-tree based). The forward-selection procedure on partial CCAs with previously selected soil factors as covariables was applied to the subset of tree-structured spatial variables and the significance of environmental models with selected spatial variables as covariables was tested using the Monte Carlo permutation test (9999 permutations) (Zhukov et al., 2019).

In the next phase of the study, the dbMEMs were forward-selected directly on the basis of the community data to explore patterns in community variation by variance partitioning between environmental and spatial influence. The significance of pure spatial and environmental fractions was tested using Monte Carlo permutation tests with 999. The scalogram approach was applied for in-detail analysis of the spatial scaling of community variation (Legendre \& Legendre, 2012). For this purpose, the two sets of CCA analyses were carried out with each of the dbMEM variables as a predictor. As a response variable, the first set of CCA analyses used raw (arcsine transformed) species data, while the second set used residuals of the environmental model in which forward-selected environmental variables functioned as predictors (Chudomelová et al., 2017). From each CCA, we extracted R2adj for individual dbMEMs and plotted them into juxtaposed barplots (Chang et al., 2013). Phytoindication estimation of the ecological factors (Didukh, 2011) was used to find an ecological interpretation of spatial structures in community composition not explained by environmental variables (Zhukov et al., 2017).

The environmental factors were applied to CCA-ordination by enfit function from the vegan library (Oksanen et al., 2018). The constrained ordination approaches (correspondence or redundancy analysis) allowed us to assess the effects of the soil moisture as an explanatory variable on the invertebrate community with temporal, spatial, environmental factors and soil type as condition variables. The detrended correspondence analysis (DCA) was used to determine whether species responses are primarily monotonic or primarily unimodal. To do this, the length of the first major gradient of variation in community data was estimated (ter Braak \& Prentice, 1988).

If gradient length is more than two standard deviation, then constrained correspondence analysis (CCA) must be selected as ordination approach. Otherwise constrained redundancy analysis (RDA) is most suitable. All statistical analyses were conducted in R (v. 3.5.0., R Foundation for Statistical Computing, Vienna, AT), using the following packages: vegan (v. 2.5-2, https://CRAN.R-project.org/package=vegan) for the multivariate analysis and for the computation of global and partial Moran's I. (Oksanen et al., 2019), adespatial (v. 0.3-2. https://CRAN.Rproject.org/package=adespatial) for the forward selection and for the generation of spatial filters (Dray et al., 2012), dixon for testing the spatial segregation and association based on nearest-neighbour contingency table analysis (De la Cruz, 2008), spatstat for density estimation of the tree stems' spatial distribution (Baddeley \& Turner, 2005).

\section{Results}

The plant community was represented by 43 species, of which $18.6 \%$ were phanerophytes, $39.5 \%$ were hemicryptophytes, $9.3 \%$ were therophytes, $7.0 \%$ were geophytes (Table 1). Quercus robur L. and Ulmus laevis Pall. were characterized by the largest projection cover $(23.5 \%$ and $13.3 \%$ respectively) among phanerophytes.

\section{Table 1}

Plant community composition and descriptive statistic of the plant species projective cover

\begin{tabular}{|c|c|c|c|c|c|}
\hline \multirow[t]{2}{*}{$\begin{array}{l}\text { Raunkiær plant life-form } \\
\text { and species }\end{array}$} & $\begin{array}{c}\text { Beta- } \\
\text { distribution } \\
\text { shape para- } \\
\text { meters }\end{array}$ & \multirow[t]{2}{*}{$\begin{array}{l}\text { Projective } \\
\text { cover, } \%\end{array}$} & \multirow[t]{2}{*}{$\begin{array}{l}\text { Vari- } \\
\text { ance }\end{array}$} & \multicolumn{2}{|c|}{$\begin{array}{l}\text { Confidence } \\
\text { interval }\end{array}$} \\
\hline & Alpha Beta & & & $2.5 \%$ & $97.5 \%$ \\
\hline \multicolumn{6}{|c|}{ Phanerophytes } \\
\hline Acer negundo L. & $0.25 \quad 31.98$ & 0.79 & 0.02 & 0.52 & 1.12 \\
\hline Fraxinus excelsior $\mathrm{L}$. & 0.0198 .98 & & 0.0001 & 0.00 & 0.03 \\
\hline Populus nigra $\mathrm{L}$. & $0.05 \quad 10.25$ & & 0.05 & 0.22 & 1.11 \\
\hline Pyrus communis $\mathrm{L}$. & $0.16 \quad 2.29$ & 6.43 & 1.74 & 4.29 & 9.29 \\
\hline Quercus robur $\mathrm{L}$. & $1.68 \quad 5.49$ & 23.48 & 2.20 & 20.57 & 26.24 \\
\hline Salix alba $\mathrm{L}$. & $0.03 \quad 13.93$ & 0.19 & 0.01 & 0.05 & 0.55 \\
\hline Ulmus laevis Pall. & $1.85 \quad 12.05$ & 13.31 & 0.77 & 11.69 & 15.04 \\
\hline U. minor Mill. & 0.00998 .98 & 0.010 & 0.0001 & 0.00 & 0.029 \\
\hline \multicolumn{6}{|c|}{ Nanophanerophytes } \\
\hline Acer tataricum & $0.61 \quad 10.54$ & 49 & 0.43 & 4.34 & 6.84 \\
\hline Amol & $0.33 \quad 22.15$ & & 0.06 & 1.05 & 1.98 \\
\hline Berberis vulgaris L. & 0.0198 .98 & 0.010 & 0.0001 & 0.00 & 0.029 \\
\hline Cormus sanguinea L. & $0.21 \quad 9.44$ & & 0.20 & 1.50 & 3.29 \\
\hline $\mathrm{Cra}$ & $0.30 \quad 13.31$ & & 0.15 & 1.56 & 3.04 \\
\hline Euc & $0.08 \quad 20.28$ & 38 & 0.02 & 0.14 & 0.62 \\
\hline Frangula alnus & $0.04 \quad 16.73$ & 6 & 0.01 & 0.10 & 0.62 \\
\hline Parthenocissus quinquefolia (L.) Planch. & 0.00932 .31 & 0 & 0.001 & 0.00 & 0.086 \\
\hline Rhamnus cat & 0.01999 .93 & 0. & 0.0002 & 0.00 & 0.048 \\
\hline$R u b$ & $0.13 \quad 28.07$ & 046 & 0.02 & 0.25 & 0.75 \\
\hline & $0.29 \quad 16.85$ & 68 & 0.09 & 1.17 & 2.36 \\
\hline \multicolumn{6}{|c|}{ Hemicryptophytes } \\
\hline $\begin{array}{l}\text { Alliaria petiolata (M.Bieb.) Cavara et } \\
\text { Grande }\end{array}$ & $0.35 \quad 16.71$ & 2.05 & 0.11 & 1.49 & 2.77 \\
\hline thriscus sylvestris (L.) Hoffm. & $0.07 \quad 22.40$ & 0.32 & 0.01 & 0.14 & 0.62 \\
\hline Arctium lappa L. & $0.19 \quad 18.11$ & & 0.05 & 0.70 & 1.63 \\
\hline Brachypodiu & 0.1156 .72 & & 0.003 & 0.10 & 0.32 \\
\hline Caly & $0.08 \quad 41.73$ & 19 & 0.004 & 0.09 & 0.35 \\
\hline Can & $0.15 \quad 32.11$ & 0.4 & 0.01 & 0.29 & 0.75 \\
\hline & $0.60 \quad 26.21$ & & 0.08 & 1.79 & 2.85 \\
\hline$C y$ & 0.00932 .31 & 0.029 & 0.001 & 0.00 & 0.086 \\
\hline & $0.36 \quad 11.20$ & & 0.24 & 2.30 & 4.19 \\
\hline & $0.45 \quad 37.73$ & & 0.03 & 0.90 & 1.56 \\
\hline & $0.37 \quad 18.98$ & & 0.09 & 1.37 & 2.52 \\
\hline$a c a \mathrm{~L}$. & 0.01999 .93 & 0.019 & 0.0002 & 20.00 & 0.048 \\
\hline oralis $\mathrm{L}$. & 0.09107 .15 & 0.09 & 0.001 & 0.04 & 0.14 \\
\hline phularic & $0.30 \quad 25.05$ & 1.17 & 0.04 & 0.81 & 1.61 \\
\hline & $0.38 \quad 17.82$ & 2.11 & 0.11 & 1.56 & 2.83 \\
\hline . & 0.02436 .36 & 0.067 & 0.002 & 0.010 & 0.181 \\
\hline Urtica dioica L. & $0.65 \quad 9.11$ & 6.68 & 0.58 & 5.40 & 8.30 \\
\hline \multicolumn{6}{|c|}{ Therophytes } \\
\hline$\overline{\text { Anthr }}$ & $\begin{array}{ll}0.93 & 8.03\end{array}$ & 10.35 & 0.93 & 8.64 & 12.33 \\
\hline Erodium ct & 0.01999 .93 & 0.019 & 0.0002 & 20.00 & 0.048 \\
\hline & $2.85 \quad 21.92$ & & 0.40 & 10.37 & 12.74 \\
\hline nedia (L.) Vill & $0.74 \quad 10.78$ & 6.42 & 0.48 & 5.19 & 7.80 \\
\hline \multicolumn{6}{|c|}{ Geophytes } \\
\hline & $0.24 \quad 2.09$ & 10.48 & 2.81 & 7.62 & 14.05 \\
\hline Humulus lupulus L. & 0.04640 .42 & 0.114 & 0.003 & 0.038 & 0.248 \\
\hline Lamium album $\mathrm{L}$. & 0.01999 .93 & 0.019 & 0.0002 & 0.00 & 0.048 \\
\hline
\end{tabular}

Acer tataricum L., Cornus sanguinea L., and Crataegus monogyna Jacq. had the largest projection cover among the nanophanerophytes $(5.5 \%, 2.2 \%$, and $2.2 \%$ respectively). Urtica dioica L. (6.7\%) and Geranium robertianum L. (3.1\%) had the largest projection cover among hemicryptophytes. Galium aparine L. (6.4\%) and Anthriscus cerefolium (L.) Hoffm $(10.4 \%)$ had the largest projection cover among therophytes $(6.4 \%$ and $10.4 \%$ respectively). Convallaria majalis $\mathrm{L}$. had the largest projection cover among geophytes (10.5\%).

The forest overstorey included Quercus robur L. (18.7\% of total tree stems), Ulmus laevis Pall. (39.0\%), and Pyrus communis L. (5.7\%). The forest understory included Acer tataricum L. (16.3\% of total tree stems), Crataegus monogyna Jacq. (8.9\%), and Euonymus europaeus L. 
(11.4\%). The distance from the sampling locations to Quercus robur stems was $3.8 \pm 0.21 \mathrm{~m}$ (maximum $-11.4 \mathrm{~m}$ ), accounted for $2.7 \pm 0.16 \mathrm{~m}$ (maximum $-8.8 \mathrm{~m}$ ) to Ulmus laevis stems, $9.3 \pm 0.56 \mathrm{~m}$ (maximum $19.3 \mathrm{~m}$ ) to Pyrus communis stems, $5.8 \pm 0.32 \mathrm{~m}$ (maximum $-13.4 \mathrm{~m}$ ) to Acer tataricum stems, $5.8 \pm 0.32 \mathrm{~m}$ (maximum $-13.4 \mathrm{~m}$ ) to Crataegus monogyna stems, and $6.4 \pm 0.31 \mathrm{~m}$ (maximum $-14.2 \mathrm{~m}$ ) to Euonymus europaeus. Overall test of random labelling revealed the total nonrandom distribution of the tree stems within the site (overall test of random labelling 146.6, P-value of the overall test from the asymptotic chi-square distribution with the appropriate degrees of freedom equaled $<0.01$ ) (Table 2).

\section{Table 2}

The nearest-neighbour contingency table and Dixon's spatial segregation test for tree species

\begin{tabular}{|c|c|c|c|c|c|c|c|}
\hline \multicolumn{2}{|c|}{ Species } & $\begin{array}{l}\text { A.ta- } \\
\text { taricum }\end{array}$ & $\begin{array}{l}\text { C.mo- } \\
\text { nogyna }\end{array}$ & $\begin{array}{l}\text { E. euro- } \\
\text { paeus }\end{array}$ & $\begin{array}{l}\text { P.com- } \\
\text { munis }\end{array}$ & Q.robur & U. laevis \\
\hline \multirow{4}{*}{$\begin{array}{l}\text { A.tata- } \\
\text { ricum }\end{array}$} & Observed & 12 & 2 & 2 & 1 & 1 & 2 \\
\hline & Expected & 3.11 & 1.8 & 2.3 & 1.15 & 3.77 & 7.87 \\
\hline & $\mathrm{S}$ & 0.91 & 0.05 & -0.07 & -0.06 & -0.64 & -0.77 \\
\hline & $p$-value & $<0.01$ & 0.70 & 0.76 & 0.70 & 0.09 & $<0.01$ \\
\hline \multirow{4}{*}{$\begin{array}{l}\text { C. mo- } \\
\text { nogyna }\end{array}$} & Observed & 2 & 1 & 1 & 0 & 2 & 5 \\
\hline & Expected & 1.8 & 0.9 & 1.26 & 0.63 & 2.07 & 4.33 \\
\hline & $\mathrm{S}$ & 0.05 & 0.05 & -0.11 & $-\operatorname{Inf}$ & -0.02 & 0.11 \\
\hline & $p$-value & 0.70 & 0.64 & 0.68 & 0.32 & 0.74 & 0.55 \\
\hline \multirow{4}{*}{$\begin{array}{c}\text { E. euro- } \\
\text { paeus }\end{array}$} & Observed & 0 & 0 & 10 & 0 & 2 & 2 \\
\hline & Expected & 2.3 & 1.26 & 1.49 & 0.8 & 2.64 & 5.51 \\
\hline & $\mathrm{S}$ & $-\operatorname{Inf}$ & -Inf & 1.32 & $-\operatorname{Inf}$ & -0.14 & -0.59 \\
\hline & $p$-value & 0.06 & 0.20 & $<0.01$ & 0.32 & 0.54 & 0.07 \\
\hline \multirow{4}{*}{$\begin{array}{l}\text { P.com- } \\
\text { munis }\end{array}$} & Observed & 0 & 0 & 0 & 6 & 0 & 1 \\
\hline & Expected & 1.15 & 0.63 & 0.8 & 0.34 & 1.32 & 2.75 \\
\hline & $\mathrm{S}$ & $-\operatorname{Inf}$ & $-\operatorname{Inf}$ & $-\operatorname{Inf}$ & 2.06 & $-\operatorname{Inf}$ & -0.59 \\
\hline & $p$-value & 0.19 & 0.33 & 0.33 & $<0.01$ & 0.20 & 0.14 \\
\hline \multirow{4}{*}{ Q. robur } & Observed & 2 & 2 & 3 & 0 & 9 & 7 \\
\hline & Expected & 3.77 & 2.07 & 2.64 & 1.32 & 4.15 & 9.05 \\
\hline & $\mathrm{S}$ & -0.31 & -0.02 & 0.06 & $-\operatorname{Inf}$ & 0.47 & -0.17 \\
\hline & $p$-value & 0.28 & 0.75 & 0.52 & 0.23 & 0.04 & 0.41 \\
\hline \multirow{4}{*}{ U. laevis } & Observed & 0 & 4 & 3 & 1 & 6 & 34 \\
\hline & Expected & 7.87 & 4.33 & 5.51 & 2.75 & 9.05 & 18.49 \\
\hline & $\mathrm{S}$ & $-\operatorname{Inf}$ & -0.04 & -0.29 & -0.46 & -0.21 & 0.59 \\
\hline & $p$-value & $<0.01$ & 0.82 & 0.27 & 0.21 & 0.20 & $<0.01$ \\
\hline
\end{tabular}

Note: Observed count - observed nearest neighbour count; Expected count - expected nearest neighbour counts; $\mathrm{S}$ - segregation measure (values of $\mathrm{S}$ larger than 0 indicate that species is segregated; the larger the value of $\mathrm{S}$, the more extreme is the segregation; values of $\mathrm{S}$ less than 0 indicate that species was found as neighbour of itself less than expected under random labeling; values of $\mathrm{S}$ close to 0 are consistent with random labelling of the neighbours of species); P-value - on the basis of asymptotic normal distribution of the $\mathrm{Z}$ statistic.

The species-specific test of random labelling showed the nonrandom segregated distribution of Acer tataricum (segregation measure 11.1, $\mathrm{P}<$ 0.01 ), Pyrus communis (segregation measure $\mathrm{S}=2.1, \mathrm{P}<0.01$ ), Quercus $\operatorname{robur}(\mathrm{S}=0.5, \mathrm{P}=0.04)$, and Ulmus laevis $(\mathrm{S}=0.6, \mathrm{P}<0.01)$. Crataegus monogyna and Euonymus europaeus were distributed randomly. The nearest neighbour of Acer tataricum was less likely to be Ulmus laevis $(\mathrm{S}=-0.77, \mathrm{P}<0.01)$. There was no direct spatial connection between Acer tataricum and other trees. Crataegus monogyna, Pyrus communis, Quercus robur and Euonymus europaeus were not segregated from all other species. The nearest neighbour of Ulmus laevis was less likely to be Acer tataricum ( $\mathrm{S}=\operatorname{Inf}, \mathrm{P}<0.01$ ).

Soil mechanical impedance in the $0-5 \mathrm{~cm}$ surface layer was $0.72 \pm$ $0.01 \mathrm{MPa}$ (Fig. 2). Until the depth of 35-40 cm, the changes of soil mechanical impedance were insignificant, while the local maximum of this soil property was observed at the depth of $15-20 \mathrm{~cm}$. Below the depth of $40-45 \mathrm{~cm}$, there was seen a rapid increase in the soil mechanical impedance, resulting in the soil mechanical impedance at the depth of 95$100 \mathrm{~cm}$ accounting for $3.69 \pm 0.09 \mathrm{MPa}$. This indicated that the soil mechanical impedance within the investigated polygon can serve as a significant limiting factor that influences the structure of the herbaceous vegetation.

Soil electrical conductivity of the soil surface layer was $0.49 \pm$ $0.06 \mathrm{dSm} / \mathrm{m}$ (Fig. 3). In $6.6 \%$ of cases the soil electrical conductivity value was higher than $2 \mathrm{dSm} / \mathrm{m}$. This value was a marker for a critical level of the soluble salt content in soil, able to restrict plant growth.
Depth of forest litter varied $(0-4 \mathrm{~cm})$ with average value of $2.23 \pm$ $0.07 \mathrm{~cm}$. The moisture content in the soil surface layer at the time of the study was $3.58 \pm 0.24 \%$. The bulk density of soil surface layer varied widely $\left(0.33-1.48 \mathrm{~g} / \mathrm{cm}^{3}\right)$. The macroaggregates larger than $10 \mathrm{~mm}$, the proportion of which was $23.46 \pm 0.98 \%$ (Fig. 4), had the greatest role in the soil aggregate structure. The gradient length of the first major gradient of variation in community data, estimated using DCA, was more than two standard deviations (2.59). Then constrained correspondence analysis (CCA) was applied as ordination approach. The model of the partial CCA of the plant community data, including all soil variables as covariables, was significant $(\mathrm{R} 2 \mathrm{adj}=0.39, \mathrm{~F}=3.03, \mathrm{P}<0.001)$. The forward selection procedure allowed us to select 6 soil variables, which explained $28.3 \%$ of the community variability $(\mathrm{F}=7.84, \mathrm{P}<0.001)$. The list of the important soil variables included the soil mechanical impedance (at the depth $0-5$, $30-35,75-80$, and $95-100 \mathrm{~cm}$ ), the soil moisture, and the soil bulk density.

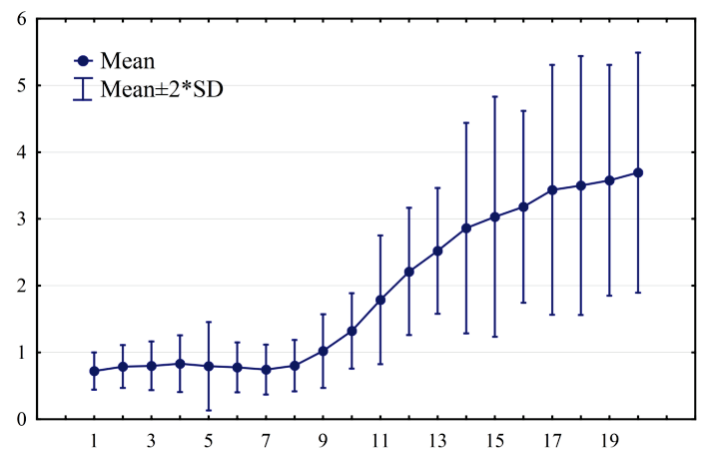

Fig. 2. Soil mechanical impedance profile distribution: $\mathrm{X}$-axis is the soil layer depth: $1-0-5 \mathrm{~cm}, \ldots 20-95-100 \mathrm{~cm}$; $\mathrm{Y}$-axis is the soil mechanical impedance, $\mathrm{MPa}$
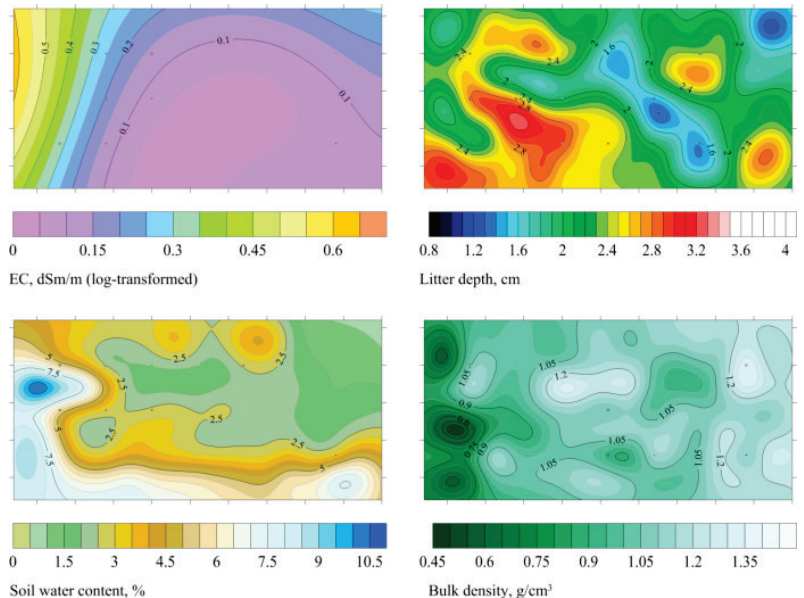

Fig. 3. Spatial variation of the soil variables within the experimental polygon: $\mathrm{X}$-axis and $\mathrm{Y}$-axis are the local coordinates, $\mathrm{m}$

There were $48 \mathrm{dbMEMs-spatial} \mathrm{variables} \mathrm{with} \mathrm{soil} \mathrm{variables} \mathrm{as} \mathrm{cova-}$ riables, which together explained $66.2 \%$ of the plant community variability. The forward selection procedure allowed us to select 18 variables, which explain $65.8 \%$ of the variability of the community $(\mathrm{F}=6.81, \mathrm{P}<$ 0.001). The model of CCA, including all dbMEMs-tree distance variables with soil variables as covariates, was significant $(\mathrm{R} 2 \mathrm{adj}=0.25, \mathrm{~F}=2.15$, $\mathrm{P}<0.001)$. The forward selection procedure allowed us to select two variables (Fig. 5), which explains $14.3 \%$ of the variability of the plant community $(\mathrm{F}=15.76, \mathrm{P}<0.001)$. The model of the partial CCA of the plant community data, including all phytoindicator variables as covariables, was significant $(\mathrm{R} 2 \mathrm{adj}=0.30, \mathrm{~F}=4.65, \mathrm{P}<0.001)$. The forward selection procedure allowed us to select 3 phytoindicator variables, which explain $28.4 \%$ of the community variability $(\mathrm{F}=14.7, \mathrm{P}<0.001)$. The list of the important phytoindicator variables included the soil water regime (Hd), the soil aeration (Ae), and light (Lc). The unexplained variation accounts for $65.1 \%$. The variation explained solely by soil variables equaled $1.6 \%$, while the variation explained both by spatial and soil va- 
riables was $6.2 \%$. The soil, spatial and tree distance variables were able to explain $6.1 \%$ of the community variation. The variation explained by pure spatial variables equaled $11.0 \%$. The role of the other sources of the variation was considerably low. The majority of the tree-distance structured variation in plant community composition was broad-scaled (captured by dbMEMs-tree variables with lowest numbers). The soil, phytoindicator, and spatial effects were able to account for mainly broad- and mesoscale tree-distance structured variation. The pure tree induced spatial effect on
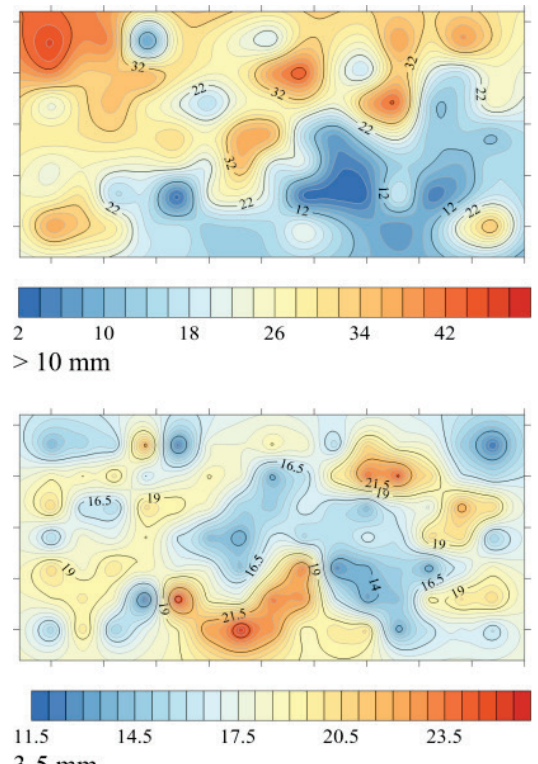

3-5 mm
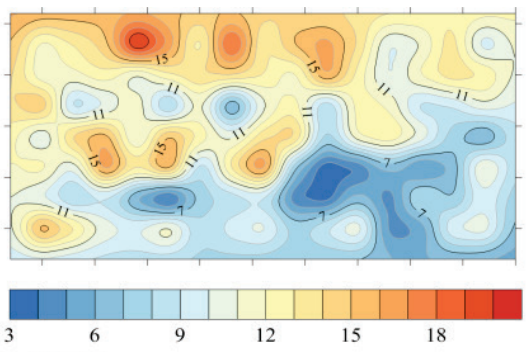

$7-10 \mathrm{~mm}$
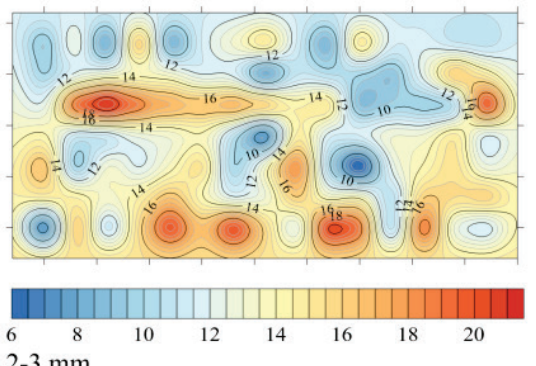

$2-3 \mathrm{~mm}$
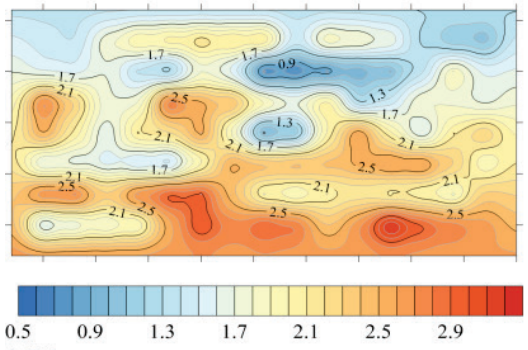

$0.5-1 \mathrm{~mm}$
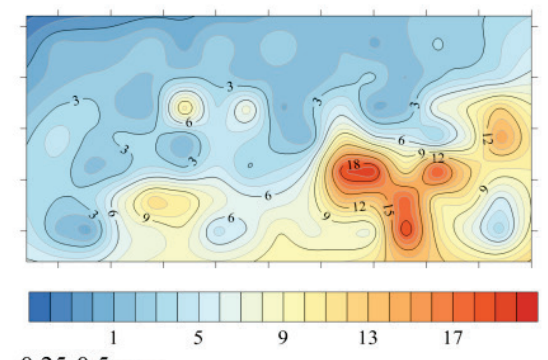

$0.25-0.5 \mathrm{~mm}$ the plant community was found to be statistically significant, covering the broad- and partly mesoscale diapason of the community variation.

The spatial scalograms were left-skewed asymmetric (Fig. 7). DbMEM-tree variables may improve the explanation of the plant community variation by the spatial variables. The soil and phytoindicator effects were able to account for spatially structured variation. The pure spatial effect on the plant community was found to be statistically significant,
covering the broad-and mesoscale diapason of the community variation.
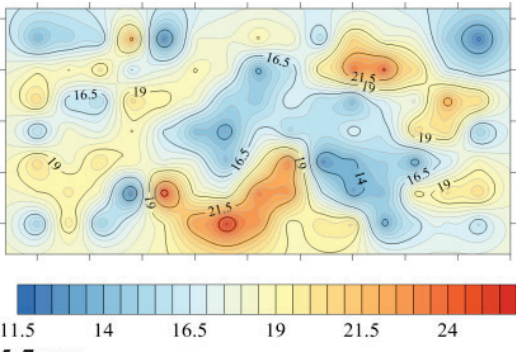

$5-7 \mathrm{~mm}$
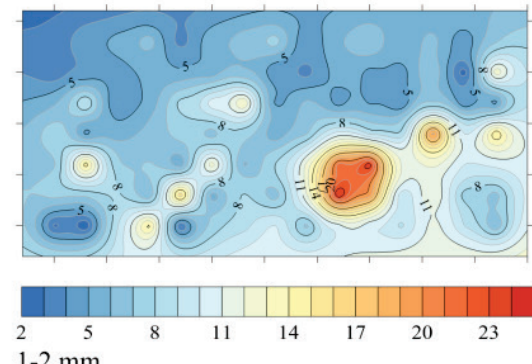

$1-2 \mathrm{~mm}$
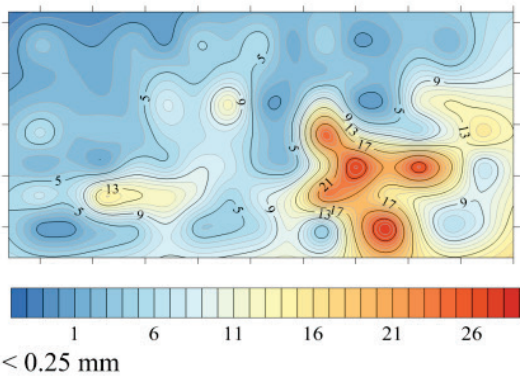

Fig. 4. Spatial variation of the aggregate fractions: $\mathrm{X}$-axis and $\mathrm{Y}$-axis are the local coordinates, $\mathrm{m}$

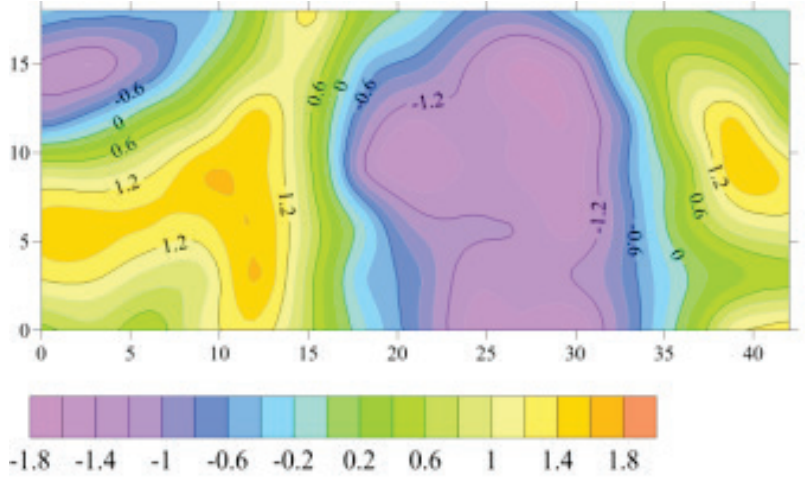

dbMEM I tree distance variable
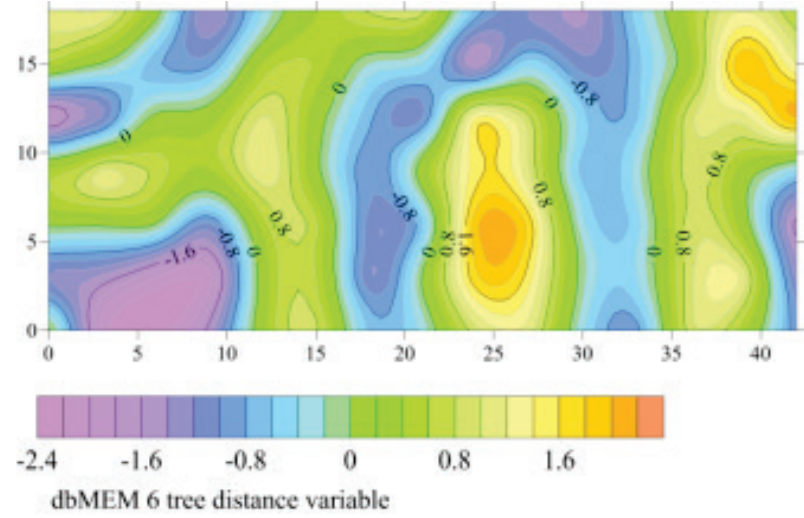

Fig. 5. Spatial variation of the dbMEMs-tree distance variables within the experimental polygon: $\mathrm{X}$-axis and $\mathrm{Y}$-axis are the local coordinates, $\mathrm{m}$

The variation in plant community structure may be explained by soil mechanical impedance at depths of $0-5,30-35,35-40,45-50$, and 95 $100 \mathrm{~cm}$, the soil bulk density, the moisture content, and the portion of $2-$ $3 \mathrm{~mm}$ aggregate fractions (Table 3 ). The spatial effect accounted for variation explained by soil mechanical impedance at depths of $35-40,45-50$, and $95-100 \mathrm{~cm}$, soil moisture, and aggregate fractions. There was no phytoindicator partial effect on explanatory power of the soil mechanical impedance, and taking into account the phytoindicator effect led to increase in the explanatory power of the edaphic parameters. The explanato- ry power of the soil bulk density and aggregate fractions considerably decreased after taking into account tree partial effect. A significant relationship was found between the soil induced community structure and the phytoindication values of soil water regime, variability of damping, total salt regime, and continentality of climate (Table 4). A significant relationship was found between the pure spatial component of the community variation and many of the phytoindicator estimations, of which the variability of damping and humidity were of the greatest importance. There was no significant tree distance effect on the phytoindicator estimations. 

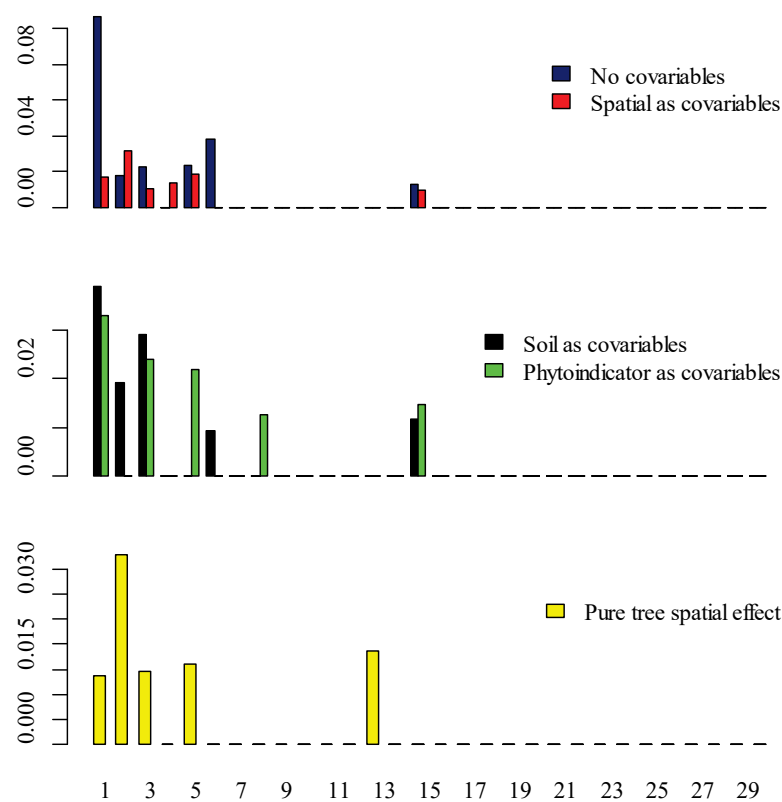

Fig. 6. Scalograms illustrating the scaling of tree structured variation in plant community data (no variables as covariables, blue bars) and residuals of the spatial models (red bars), soil models (black bars), plant models (green bars) and pure tree effect (yellow bars); the value of R2adj

is the variation explained by individual dbMEM-tree variables; the dbMEMs are ordered decreasingly according to the scale of spatial patterns they represent ( $\mathrm{x}$-axis is the number of dbMEM; dbMEM 1 represents the broadest scale, dbMEM 30 the finest scale)
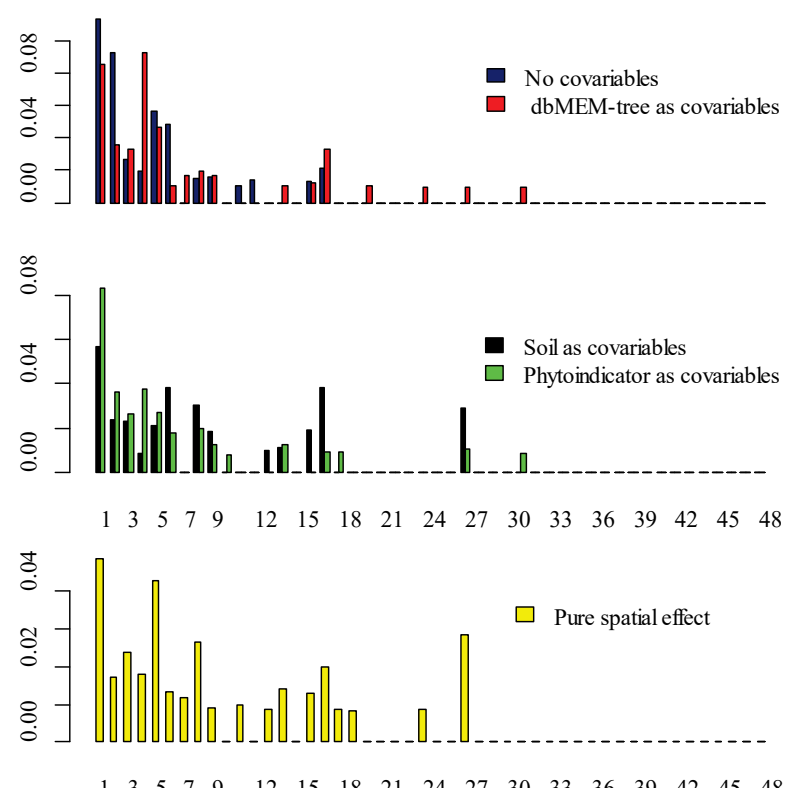

Fig. 7. Scalograms illustrating the scaling of spatial structured variation in plant community data (No variables as covariables, blue bars) and residuals of the tree distance models (red bars), soil models (black bars), phytoindicator models (green bars) and pure spatial effect (yellow bars); the value of R2adj is the variation explained by individual dbMEM-spatial variables; the dbMEMs are ordered decreasingly according to the scale of spatial patterns they represent ( $\mathrm{x}$-axis is the number of dbMEM; dbMEM 1 represents the broadest scale, dbMEM 48 - the finest scale)

\section{Discussion}

The ground vegetation layer is the most diverse plant community in the forest ecosystems (Gilliam, 2007). The niche assembly and dispersal assembly are discussed as the alternative explanations for community structure (Dallas \& Drake, 2014a; Faly \& Brygadyrenko, 2014; Brygady- renko, 2015, 2019). The niche assembly concept suggests that community structure is largely affected by environmental factors (Weiher et al., 2011b). In our investigation, we considered the effect on the herbaceous plant community of the forest ecosystem of such environmental factors, as the soil conditions and the impact of tree plants. Dispersal assembly suggests that community is structured by the ability of species to reach new habitats (Dallas \& Drake, 2014b). That is why spatial variables may be considered as the effective determinants of community composition (Weiher et al., 2011a). In our work, the spatial component of the variation was investigated as a factor of the plant community structure.

Table 3

Variation in plant community structure explained by models with soil variables (statistically significant predictors are presented only)

\begin{tabular}{|c|c|c|c|c|c|c|c|c|}
\hline \multirow{3}{*}{ Variable } & \multirow{3}{*}{$\begin{array}{c}\text { Marginal } \\
\text { effect } \\
R_{a d j}^{2}\end{array}$} & \multirow{3}{*}{$\begin{array}{c}p- \\
\text { value }\end{array}$} & \multicolumn{6}{|c|}{ Partial effect } \\
\hline & & & \multicolumn{2}{|c|}{ spatial } & \multicolumn{2}{|c|}{ phytoindicator } & \multicolumn{2}{|c|}{ tree } \\
\hline & & & $R_{a d j}^{2}$ & $p$-value & $R_{a d j}^{2}$ & $p$-value & $R_{a d j}^{2}$ & - \\
\hline \multicolumn{9}{|c|}{ Soil mechanical impedance at depth, MPa } \\
\hline 5 & $\overline{041}$ & 0.001 & 0.015 & & 0.030 & 0.001 & .026 & 002 \\
\hline & 70 & 0.001 & 0.0 & & 0. & 0. & & .001 \\
\hline & 0.033 & 0 . & 0.0 & & 0.029 & 0.001 & 0.029 & 0.001 \\
\hline & & & 0.0 & & 0.008 & 0.031 & 0.019 & 0.001 \\
\hline & 07 & & 0.008 & 0.082 & 0.008 & 0.039 & .013 & 0.009 \\
\hline \multicolumn{9}{|c|}{ Other edaphic parameters } \\
\hline & & & 00 & & 0.033 & 0.001 & -0.009 & 0.883 \\
\hline Moisture & 15 & 0.025 & 0.004 & 0.179 & 0.033 & 0.001 & 0.039 & 0.024 \\
\hline \multicolumn{9}{|c|}{ Aggregate fractions, $\mathrm{mm}$} \\
\hline & & 023 & 0.008 & 0.067 & 0.027 & 0.001 & 0.006 & 0.206 \\
\hline $7-10$ & 0.005 & 0.130 & 0.003 & 0.241 & 0.024 & 0.003 & -0.009 & 0.873 \\
\hline
\end{tabular}

Note: marginal effect represents variation explained by a given variable without the effect of other variables in the model; $\mathrm{P}$-value accounting for autocorrelation was the significance of soil model with selected eigenvector-based spatial variables (dbMEMs) as covariables; moisture - moisture of soil, \%; density - soil density, $\mathrm{g} / \mathrm{cm}^{3}$.

Herb-layer species are known to be sensitive and informative ecological indicators (Weiher et al., 2011a). In our investigation, the phytoindication estimations of the certain ecological factors were formally considered as a special source of the variation of plant community structure. The phytoindication estimates are markers of the coordinated dynamics of plant community species, which is due to the similarity of plant responses to the effect of certain environmental factors. It should be noted that we are far from the idea that a formal name of the indicated factors is fully consistent with the real environmental processes occurring within the investigated polygon. Such an opinion is due to the fact that meaningful interpretation of phytoindication scales is based on the data obtained as a result of studying of the plant species responses to ecological factors at the scale level of the landscape or physical geographic zone (Didukh, 2011). Therefore, the interpretation of the phytoindication scales at the level of ecosystem should be treated with a certain degree of caution.

Herbaceous species are sensitive to the changes in environmental conditions (von Oheimb \& Härdtle, 2009). The structure of plant community was revealed to correlate with physical properties of soil, but this correlation was due to the coordinated spatial trends of both vegetation and soil properties. Ground-layer vegetation in temporal forests is greatly affected by the overstorey composition and structure (Barbier et al., 2008). The pattern of soil properties under single forest trees is generally developed with radial symmetry to the tree, varying with distance from the tree trunk (Zinke, 1962). Trees were revealed to act as a significant and complicated structuring factor, which independently influences both the vegetation community and the physical properties of soil. The tree species composition may take an effect on the dynamics of herbaceous species (Bratton, 1976) by changing light availability (Breshears et al., 1997) and enhancing the spatial heterogeneity of soil (Andivia et al., 2015).

The role of the trees in forming the spatial patterns covers mainly the broad-scale component, allowing one to consider the influence of the tree canopy on the permeability to solar radiation, as the main mechanism of such structuring effect. The limiting factors act as an environmental filter that affects both species richness and composition of the plant community. The competition for light and water is the main mechanism of the overstorey effect on the ground-layer vegetation (Burrascano et al., 2011). This 
result is consistent with hypothesis that environmental filtering is probably not very important at finer scales (Chudomelová et al., 2017). Neutral processes become weaker as a consequence of increasing heterogeneity of the environmental conditions (Nettesheim et al., 2018). By scaling down, the number of individuals within a given grain or extent is reduced, and individual-based stochastic processes become more important (Chase, 2014). As the size of the sampling plot decreased, the relative importance of environmental factors declined predominantly due to the reduction of environmental variability at finer scales (Frelich et al., 2003).

Community composition may be spatially structured regardless of environment if dispersal limitation is the main assembly process (Aiba et al., 2012). Obtained data revealed that the pure spatial component was able to explain $11.0 \%$ of the plant community variation. Spatial distances may be considered as surrogate for dispersal through space over time (Karst et al., 2005). The spatial component of the plant community variation may be caused by the impact both of the unmeasured environmental variables with spatial structure (Legendre et al., 2009) and the effect of neutral nature (Hubbell, 2001; Chave, 2004; Hubbell, 2005; Rosindell et al., 2011). The pure spatial influence had a complicated structure, which was confirmed by the high number of significant CCA-axes extracted after application of the spatial variables as predictors and their wide-scale range. Also, the pure spatial component was shown to be a statistically significant predictor of the phytoindication factors, revealing the important role of the non-measured factors in the formation of the spatial patterns of vegetation. The use of space across different scales in the community analysis could be useful. The pure spatial component covered the broadand medium-scale range. As a mechanism of the occurrence of pure spatial component plant community variation one can assume the phenomena of species dispersal-limitation and vegetative growth, as well as competitive interaction between plant species (Tuomisto, 2003). The biotic interactions (e.g., competition) and historical processes, such as colonization and local extinctions, are factors of great impact on species richness and composition (Pausas \& Austin, 2001). The herbaceous species actively compete for soil nutrients (Lyon \& Sharpe, 2003). As scale becomes finer, dispersal or biotic processes such as interspecies interactions increase their importance (Gazol \& Ibáñez, 2010).

\section{Table 4}

Significance of regression between subplot-based phytoindicator scale values and pure soil effects in the species data (first significant CCA axis with soil predictors as explanatory variables and selected spatial and tree-distance variables as covariables, $\mathrm{F}=1.67, \mathrm{P}<0.001$ ), pure space (first five significant CCA axes with spatial predictors as explanatory variables and selected soil and tree-distance variables as covariables, $\mathrm{F}=3.17, \mathrm{P}<0.001$ ), pure tree distance effect (first significant CCA with tree distance predictors as explanatory variables and selected soil and spatial variables as covariables)

\begin{tabular}{lcccccc}
\hline $\begin{array}{l}\text { Phytoindi- } \\
\text { cator scale* }\end{array}$ & $\begin{array}{c}\text { Soil } \\
\text { effect } R_{\text {adj }}^{2}\end{array}$ & $p$-value & $\begin{array}{c}\text { Pure spatial } \\
\text { partial } \\
\text { effect } R_{\text {adj }}^{2}\end{array}$ & $p$-value & $\begin{array}{c}\text { Tree partial } \\
\text { effect } R_{\text {adj }}^{2}\end{array}$ & $p$-value \\
\hline $\mathrm{Hd}$ & 0.04 & 0.04 & 0.02 & 0.26 & 0.01 & 0.17 \\
$\mathrm{fH}$ & 0.03 & 0.07 & 0.19 & 0.00 & 0.00 & 0.40 \\
$\mathrm{Rc}$ & 0.00 & 0.42 & 0.06 & 0.04 & 0.00 & 0.43 \\
$\mathrm{Sl}$ & 0.04 & 0.06 & 0.08 & 0.02 & -0.01 & 0.77 \\
$\mathrm{Ca}$ & 0.00 & 0.32 & 0.07 & 0.04 & -0.01 & 0.85 \\
$\mathrm{Nt}$ & 0.03 & 0.08 & 0.13 & 0.00 & 0.02 & 0.09 \\
$\mathrm{Ae}$ & -0.02 & 0.89 & -0.04 & 0.93 & -0.01 & 0.52 \\
$\mathrm{Tm}$ & 0.04 & 0.04 & 0.09 & 0.02 & -0.01 & 0.83 \\
$\mathrm{Om}$ & -0.01 & 0.69 & 0.28 & 0.00 & 0.00 & 0.31 \\
$\mathrm{Kn}$ & 0.07 & 0.01 & 0.15 & 0.00 & -0.01 & 0.70 \\
$\mathrm{Cr}$ & -0.01 & 0.52 & 0.18 & 0.00 & 0.00 & 0.24 \\
$\mathrm{Lc}$ & 0.01 & 0.23 & 0.07 & 0.03 & -0.01 & 0.84 \\
\hline
\end{tabular}

Note: phytoindicator scale*: $\mathrm{Hd}$ - soil water regime; $\mathrm{fH}$ - variability of damping; $\mathrm{Rc}$ - soil acidity; $\mathrm{Sl}$ - total salt regime; $\mathrm{Ca}$ - carbonate content in soil; $\mathrm{Nt}$ - nitrogen content in soil; Ae - soil aeration; Tm - thermal climate (thermoregime); Om humidity; $\mathrm{Kn}$ - continentality of climate; $\mathrm{Cr}$-cryo-climate; Lc-light.

Our results correlate with the statement that the soil properties largely influence the plant community. The understorey species composition of the poplar-willow forest was best explained by the soil mechanical impedance, litter depth, soil temperature and soil moisture, and soil aggregate structure (Zhukov et al., 2019). Abiotic processes are generally considered as environmental filters which select those species that match the specific habitat requirements (Lososová et al., 2015). The soil mechanical impedance at different depths, soil bulk density and water content, and the content of the mesoaggregates had a considerable effect on the herbaceous community. This result is consistent with evidence that root elongation stops in soil with penetrometer resistance of $0.8-5.0 \mathrm{MPa}$ (Greacen et al., 1968). The critical value of the soil mechanical impedance for the growth of plant root systems is $3 \mathrm{MPa}$ (Medvedev, 2009). In our investigation such value was observed from the depth of $55-60 \mathrm{~cm}$ and deeper. The coherent patterns of variation of both the plant cover and the soil mechanical impedance at the depth of 35-50 cm, soil moisture and the content of aggregates $7-10 \mathrm{~mm}$ were caused by their common response to the general impact of the spatially structured process. Soil aggregate structure is critical to plant growth. But the reverse is also true: vegetation affects soil structure at different scales and through a wide variety of mechanisms (Angers \& Caron, 1998). The scale of observation affects the relative importance of specific environmental factors (Siefert et al., 2012). The influence of the environmental factors was revealed as progressively decreasing from broader to finer spatial scales (Laliberté et al., 2009). The effect of the above-mentioned soil properties on vegetation community was independent from the phytoindication estimates of the environmental factors and the influence of trees on the spatial organization of environmental conditions. The peculiarities of the organization of the flooded soil can be considered as a source of such spatial process, which is dependent on the intensity of sediments deposition during the flood. The floodplain is one of the youngest and most dynamic elements of the relief. The complex and mosaic organization of the floodplain soil is caused by flooding. It formed during the Holocene and continues to develop actively (Yakovenko et al., 2019). Floodplain ecosystems are complicated natural complexes that are characterized by significant spatial variability (Rinklebe \& Langer, 2006). Soils in floodplain areas are affected by erosion processes and sedimentation processes, as well as transformation and translocation of the substance, leading to constant impact that forms the veins and layers of sandy or clay deposits and varying degrees of humus accumulation (Wälder et al., 2008).

\section{Conclusion}

The pure spatial component was more important to explain the variation of the herb-layer community in a riparian mixed forest than the effect of soil and tree distance variables. The pure spatial influence had a complicated structure. The important role of the non-measured factors in the formation of the spatial patterns of vegetation was revealed. The species dispersal-limitation and vegetative growth, as well as competitive interaction between plant species were suggested as a source of the pure spatial component of the herb-layer community variation. The soil mechanical impedance at different depths, soil bulk density and water content, and the content of the mesoaggregates had a considerable effect on the herbaceous community. Trees were revealed to act as a significant and complicated structuring factor, which independently influenced both the vegetation community and the physical properties of soil.

The authors are grateful to the staff of the "Dniprovsko-Orilsky" Nature Reserve for their support and assistance with this research. We thank the two anonymous reviewers for helping us to improve earlier versions of this paper.

\section{References}

Aiba, M., Takafumi, H., \& Hiura, T. (2012). Interspecific differences in determinants of plant species distribution and the relationships with functional traits. Journal of Ecology, 100(4), 950-957.

Andivia, E., Fernández, M., Alejano, R., \& Vázquez-Piqué, J. (2015). Tree patch distribution drives spatial heterogeneity of soil traits in cork oak woodlands. Annals of Forest Science, 72(5), 549-559.

Angers, D. A., \& Caron, J. (1998). Plant-induced changes in soil structure: Processes and feedbacks. Biogeochemistry, 42(1/2), 55-72.

Baddeley, A., \& Turner, R. (2005). Spatstat: An R package for analyzing spatial point patterns. Journal of Statistical Software, 12(6), 1-42. 
Barbier, S., Gosselin, F., \& Balandier, P. (2008). Influence of tree species on understory vegetation diversity and mechanisms involved-A critical review for temperate and boreal forests. Forest Ecology and Management, 254(1), 1-15.

Binkley, D., \& Giardina, C. (1998). Why do tree species affect soils? The warp and woof of tree-soil interactions. In: Plant-induced soil changes: Processes and feedbacks. Springer Netherlands, Dordrecht. Pp. 89-106.

Blanchet, F. G., Legendre, P., \& Borcard, D. (2008). Forward selection of explanatory variables. Ecology, 89(9), 2623-2632.

Blank, L., \& Carmel, Y. (2012). Woody vegetation patch types affect herbaceous species richness and composition in a Mediterranean ecosystem. Community Ecology, 13(1), 72-81.

Borcard, D., \& Legendre, P. (2002). All-scale spatial analysis of ecological data by means of principal coordinates of neighbour matrices. Ecological Modelling, $153(1-2), 51-68$

Borsukevish, L. V., \& Onishenko, V. A. (2018). Moist and occasionally flooded oakelm forests. In: Kuzemko, A. A. (Ed.). National habitat catalogue of Ukraine. FOP Y. I. Klymenko, Kyiv. Pp. 262-263.

Bratton, S. P. (1976). Resource division in an understory herb community: Responses to temporal and microtopographic gradients. The American Naturalist, 110(974), 679-693.

Breshears, D. D., Rich, P. M., Barnes, F. J., \& Campbell, K. (1997). Overstory-imposed heterogeneity in solar radiation and soil moisture in a semiarid woodland. Ecological Applications, 7(4), 1201-1215.

Brygadyrenko, V. (2015). Evaluation of the ecological niche of some abundant species of the subfamily Platyninae (Coleoptera, Carabidae) against the background of eight ecological factors. Folia Oecologica, 42, 1-18.

Brygadyrenko, V. (2019). Evaluation of ecological niches of abundant species of Poecilus and Pterostichus (Coleoptera: Carabidae) in forests of steppe zone of Ukraine. Entomologica Fennica, 27(2), 81-100.

Brygadyrenko, V. V. (2016). Effect of canopy density on litter invertebrate community structure in pine forests. Ekológia (Bratislava), 35(1), 90-102.

Bums, A. R., Stephens, W. Z., Stagaman, K., Wong, S., Rawls, J. F., Guillemin, K. \& Bohannan, B. J. (2016). Contribution of neutral processes to the assembly of gut microbial communities in the zebrafish over host development. The ISME Journal, 10(3), 655-664.

Burrascano, S., Sabatini, F. M., \& Blasi, C. (2011). Testing indicators of sustainable forest management on understorey composition and diversity in southern Italy through variation partitioning. Plant Ecology, 212(5), 829-841.

Canty, A., \& Ripley, B. (2016). Boot: Bootstrap R (S-Plus) functions. R Package Version, 1, 3-18.

Chang, L. W., Zelený, D., Li, C. F., Chiu, S. T., \& Hsieh, C. F. (2013). Better environmental data may reverse conclusions about niche- and dispersal-based processes in community assembly. Ecology, 94(10), 2145-2151.

Chase, J. M. (2014). Spatial scale resolves the niche versus neutral theory debate. Journal of Vegetation Science, 25(2), 319-322.

Chave, J. (2004). Neutral theory and community ecology. Ecology Letters, 7(3), 241-253.

Chudomelová, M., Zelený, D., \& Li, C. F. (2017). Contrasting patterns of fine-scale herb layer species composition in temperate forests. Acta Oecologica, 80, 24-31.

Cottenie, K. (2005). Integrating environmental and spatial processes in ecological community dynamics. Ecology Letters, 8(11), 1175-1182.

Dallas, T., \& Drake, J. M. (2014). Relative importance of environmental, geographic, and spatial variables on zooplankton metacommunities. Ecosphere, 5(9), 104.

Damgaard, C. F., \& Irvine, K. M. (2019). Using the beta distribution to analyse plant cover data. Journal of Ecology, 107(6), 2747-2759.

De la Cruz, M. (2008). Metodos para analizar datos puntuales. In: Maestre, F. T., Escudero, A., \& Bonet, A. (Eds.). Introduccion al analisis espacial de datos en ecologia y ciencias ambientales: Metodos y aplicaciones, asociacion espanola de ecologia terrestre. Universidad Rey Juan Carlos y Caja de Ahorros del Mediterraneo, Madrid. Pp. 76-127.

Didukh, Y. P. (2011). The ecological scales for the species of Ukrainian flora and their use in synphytoindication. Phytosociocentre, Kyiv.

Dixon, P. M. (2002). Nearest-neighbor contingency table analysis of spatial segregation for several species. Écoscience, 9(2), 142-151.

Dray, S., Pélissier, R., Couteron, P., Fortin, M. J., Legendre, P., Peres-Neto, P. R., Bellier, E., Bivand, R., Blanchet, F. G., De Cáceres, M., Dufour, A. B., Heegaard, E., Jombart, T., Munoz, F., Oksanen, J., Thioulouse, J., \& Wagner, H. H. (2012). Community ecology in the age of multivariate multiscale spatial analysis. Ecological Monographs, 82(3), 257-275.

Faly, L. I., \& Brygadyrenko, V. V. (2014). Patterns in the horizontal structure of litter invertebrate communities in windbreak plantations in the steppe zone of the Ukraine. Journal of Plant Protection Research, 54(4), 414 420.

Frelich, L. E., Machado, J.-L., \& Reich, P. B. (2003). Fine-scale environmental variation and structure of understorey plant communities in two old-growth pine forests. Journal of Ecology, 91(2), 283-293.

Gazol, A., \& Ibáñez, R. (2010). Plant species composition in a temperate forest: Multi-scale patterns and determinants. Acta Oecologica, 36(6), 634-644
Gilliam, F. S. (2007). The ecological significance of the herbaceous layer in temperate forest ecosystems. BioScience, 57(10), 845-858.

Greacen, E. L., Farrell, D. A., \& Cockroft, B. (1968). Soil resistance to metal probes and plant roots. Transactions of the 9 th Congress of the International Society of Soil Science, 1, 769-779.

Gritsan, Y. I., Kunakh, O. M., Dubinina, J. J., Kotsun, V. I., \& Tkalich, Y. I. (2019). The catena aspect of the landscape diversity of the "Dnipro-Orilsky" Natural Reserve. Journal of Geology, Geography and Geoecology, 28(3), 417-431.

Hubbell, S. (2001). The unified neutral theory of biodiversity and biogeography. Princeton University Press.

Hubbell, S. P. (2005). Neutral theory in community ecology and the hypothesis of functional equivalence. Functional Ecology, 19(1), 166-172.

Jones, C. G., Lawton, J. H., \& Shachak, M. (1994). Organisms as ecosystem engineers. Oikos, 69(3), 373

Karst, J., Gilbert, B., \& Lechowicz, M. J. (2005). Fern community assembly: The roles of chance and the environment at local and intermediate scales. Ecology, 86(9), 2473-2486.

Laliberté, E., Paquette, A., Legendre, P., \& Bouchard, A. (2009). Assessing the scalespecific importance of niches and other spatial processes on beta diversity: A case study from a temperate forest. Oecologia, 159(2), 377-388.

Legendre, P., \& Legendre, L. (2012). Numerical ecology. Ch. 6. Multidimensional qualitative data. Developments in Environmental Modelling, 24, 337-424.

Legendre, P., Mi, X., Ren, H., Ma, K., Yu, M., Sun, I. F., \& He, F. (2009). Partitioning beta diversity in a subtropical broad-leaved forest of China. Ecology, 90(3) 663-674.

Lososová, Z., Šmarda, P., Chytrý, M., Purschke, O., Pyšek, P., Sádlo, J., Tichý, L., \& Winter, M. (2015). Phylogenetic structure of plant species pools reflects habitat age on the geological time scale. Journal of Vegetation Science, 26(6), 1080-1089.

Lyon, J., \& Sharpe, W. E. (2003). Impacts of hay-scented fern on nutrition of northern red oak seedlings. Journal of Plant Nutrition, 26(3), 487-502.

Medvedev, V. V. (2009). Soil penetration resistance and penetrographs in studies of tillage technologies. Eurasian Soil Science, 42(3), 299-309.

Nettesheim, F. C., Garbin, M. L., Rajão, P. H. M., Araujo, D. S. D., \& Grelle, C. E. V. (2018). Environment is more relevant than spatial structure as a driver of regional variation in tropical tree community richness and composition. Plant Ecology and Diversity, 11(1), 27-40.

Oijen, D., Feijen, M., Hommel, P., Ouden, J., \& Waal, R. (2005). Effects of tree species composition on within-forest distribution of understorey species. Applied Vegetation Science, 8(2), 155-166.

Oksanen, J., Blanchet, F. G., Friendly, M., Kindt, R., Legendre, P., McGlinn, D. Minchin, P. R., O’Hara, R. B., Simpson, G. L., Solymos, P., Stevens, M. H. H., Szoecs, E., \& Wagner, H. (2019). Vegan: Community Ecology Package. R package version 2.5-6.

Oksanen, J., Blanchet, F. G., Kindt, R., Legendre, P., Minchin, P. R., O’Hara, R. B., Simpson, G. L., Solymos, P., Stevens, M. H. H., \& Wagner, H. (2018). Community Ecology Package. R package version 2.5-2.

Paluch, J., \& Gruba, P. (2012). Effect of local species composition on topsoil properties in mixed stands with silver fir (Abies alba Mill.). Forestry, 85(3), 413-426.

Pausas, J. G., \& Austin, M. P. (2001). Patterns of plant species richness in relation to different environments: An appraisal. Journal of Vegetation Science, 12(2), $153-166$.

R Core Team (2020). A language and environment for statistical computing. In: R: A language and environment for statistical computing. R Foundation for Statistical Computing, Vienna.

Rinklebe, J., \& Langer, U. (2006). Microbial diversity in three floodplain soils at the Elbe River (Germany). Soil Biology and Biochemistry, 38(8), 2144-2151.

Rosindell, J., Hubbell, S. P., \& Etienne, R. S. (2011). The unified neutral theory of biodiversity and biogeography at age ten. Trends in Ecology and Evolution, 26(7), 340-348

Schindler, S., O’Neill, F. H., Biró, M., Damm, C., Gasso, V., Kanka, R., van der Sluis, T., Krug, A., Lauwaars, S. G., Sebesvari, Z., Pusch, M., Baranovsky, B., Ehlert, T., Neukirchen, B., Martin, J. R., Euller, K., Mauerhofer, V., \& Wrbka, T. (2016). Multifunctional floodplain management and biodiversity effects: A knowledge synthesis for six European countries. Biodiversity and Conservation, 25(7), 1349-1382.

Schnitzler, A., Hale, B. W., \& Alsum, E. (2005). Biodiversity of floodplain forests in Europe and Eastern North America: A comparative study of the Rhine and Mississippi Valleys. Biodiversity and Conservation, 14(1), 97-117.

Siefert, A., Ravenscroft, C., Althoff, D., Alvarez-Yépiz, J. C., Carter, B. E., Glennon, K. L., Heberling, J. M., Jo, I. S., Pontes, A., Sauer, A., Willis, A., \& Fridley, J. D. (2012). Scale dependence of vegetation-environment relationships: A meta-analysis of multivariate data. Journal of Vegetation Science, 23(5), 942-951.

Stohlgren, T. J., Owen, A. J., \& Lee, M. (2000). Monitoring shifts in plant diversity in response to climate change: A method for landscapes. Biodiversity and Conservation, 9(1), 65-86.

Talbot, C. J., Bennett, E. M., Cassell, K., Hanes, D. M., Minor, E. C., Paerl, H., Raymond, P. A., Vargas, R., Vidon, P. G., Wollheim, W., \& Xenopoulos, M 397 
(2018). The impact of flooding on aquatic ecosystem services. Biogeochemistry, 141(3), 439-461.

Ter Braak, C. J. F. (1986). Canonical correspondence analysis: A new eigenvector technique for multivariate direct gradient analysis. Ecology, 67(5), 1167-1179.

ter Braak, C. J. F., \& Prentice, I. C. (1988). A theory of gradient analysis. Advances in Ecological Research, 18(C), 271-317.

Thieler, A. M., Fried, R., \& Rathjens, J. (2016). RobPer: An R package to calculate periodograms for light curves based on robust regression. Journal of Statistical Software, 69,9

Tuomisto, H. (2003). Dispersal, environment, and floristic variation of western amazonian forests. Science, 299(5604), 241-244.

von Oheimb, G., \& Härdtle, W. (2009). Selection harvest in temperate deciduous forests: Impact on herb layer richness and composition. Biodiversity and Conservation, 18(2), 271-287.

Wälder, K., Wälder, O., Rinklebe, J., \& Menz, J. (2008). Estimation of soil properties with geostatistical methods in floodplains. Archives of Agronomy and Soil Science, 54(3), 275-295.

Ward, J., Tockner, K., Arscott, D., \& Claret, C. (2002). Riverine landscape diversity. Freshwater Biology, 47(4), 517-539.

Weiher, E., Freund, D., Bunton, T., Stefanski, A., Lee, T., \& Bentivenga, S. (2011). Advances, challenges and a developing synthesis of ecological community assembly theory. Philosophical Transactions of the Royal Society B: Biological Sciences, 366(1576), 2403-2413.

Yakovenko, V. M., Dubinina, J. J., \& Zhukova, Y. O. (2019). Spatial heterogeneity of the physical properties of the soil in the floodplain of the small river. Agrology, 2(4), 219-228.

Zhukov, A. V. (2015a). Phytoindicator estimation of the multidimensional scaling of the plant community structure. Biological Bulletin of Bogdan Chmelnitskiy Melitopol State Pedagogical University, 1(1), 69-93.
Zhukov, A. V. (2015b). Influence of usual and dual wheels on soil penetration resistance: The GIS-approach. Biological Bulletin of Bogdan Chmelnitskiy Melitopol State Pedagogical University, 5(3), 73-100.

Zhukov, A. V., \& Zadorozhnaya, G. A. (2016). Spatio-temporal dynamics of the penetration resistance of recultivated soils formed after open cast mining. Visnyk of Dnipropetrovsk University, Biology, Ecology, 24(2), 324-331.

Zhukov, A. V., Andrusevich, K. V., Lapko, K. V., \& Sirotina, V. O. (2015). Geostatistical estimation of soil aggregate structure as a composite variable. Biological Bulletin of Bogdan Chmelnitskiy Melitopol State Pedagogical University, 5(3), 101-121.

Zhukov, O. V., \& Gubanova, N. L. (2015a). Diversity and dynamics of amphibians in floodplain ecosystems of the Samara river. Visnyk of Dnipropetrovsk University, Biology, Ecology, 23(1), 66-73.

Zhukov, O. V., \& Gubanova, N. L. (2015b). Dynamic stability of communities of amphibians in short-term-floodedforest ecosystems. Visnyk of Dnipropetrovsk University, Biology, Ecology, 23(2), 161-171.

Zhukov, O. V., Kunah, O. M., Dubinina, Y. Y., \& Ganzha, D. S. (2017). Diversity and phytoindication ability of plant community. Ukrainian Journal of Ecology, 7(4), 81-99.

Zhukov, O. V., Kunah, O. M., Dubinina, Y. Y., Fedushko, M. P., Kotsun, V. I., Zhukova, Y. O., \& Potapenko, O. V. (2019). Tree canopy affects soil macrofauna spatial patterns on broad- and meso-scale levels in an Eastern European poplar-willow forest in the floodplain of the River Dnipro. Folia Oecologica, 46(2), 101-114.

Zhukov, O., Kunah, O., Dubinina, Y., Zhukova, Y., \& Ganzha, D. (2019). The effect of soil on spatial variation of the herbaceous layer modulated by overstorey in an Eastem European poplar-willow forest. Ekologia Bratislava, 38(3), 253-272.

Zinke, P. J. (1962). The pattern of influence of individual forest trees on soil properties. Ecology, 43(1), 130-133. 